\title{
Biochemical variation in roe deer (Capreolus capreolus L.): are $r$-strategists among deer genetically less variable than $K$-strategists?
}

\author{
Günther B. Hartl and \\ Friedrich Reimoser
}

Forschungsinstitut für Wildtierkunde der Veterinärmedizinischen Universität Wien, Savoyenstrasse 1, A-1160 Vienna, Austria.

Tissue samples from 161 roe deer (Capreolus capreolus L.) from 5 populations in Austria were screened for allelic variation at 41 presumptive genetic loci by means of horizontal starch gel electrophoresis. The proportion of polymorphic loci ranged from 14.6 per cent to 19.5 per cent, the values for expected average heterozygosity from 3.5 per cent to $\mathbf{7 . 9}$ per cent. These values are among the highest ones yet found among deer species. The relationship between biochemical genetic variation, body size and ecological strategy of adaptation is discussed.

\section{INTRODUCTION}

Deer are one of the most extensively studied groups of large mammals with respect to electrophoretic variation in blood proteins and isoenzyme systems. Various multilocus investigations have been carried out within the past decade to evaluate the amount of genetic diversity within and among populations of white-tailed deer (Manlove et al., 1976; Ramsey et al., 1979; Baccus et al., 1983; Smith et al., 1984, 1986; Sheffield et al., 1985), fallow deer (Pemberton and Smith, 1985; Hartl et al., 1986), wild and semi-domestic reindeer (Røed, 1985a, b; 1986), moose (Ryman et al., 1977, 1980) and different subspecies of red deer (Cameron and Vyse, 1978; Gyllensten et al., 1983; Baccus et al., 1983; Dratch and Gyllensten, 1985; Hartl, 1986). In contrast the level of genetic variability in roe deer (Capreolus capreolus L.), one of the most abundant species in Central Europe, is largely unknown. Genetic variability in roe deer is of particular interest for several reasons. Among the Cervidae it is a relatively primitive, generalist species (Reimoser, 1986) which, according to Nevo (1983a, b, 1984), should harbour more genetic diversity at the molecular level than a specialist species. A very high adaptability to various habitat types is reported (Lehmann and Sägesser, 1986) and roe deer are one of the wildlife species in Central Europe thriving very well in the cultivated landscape. Concerning the high variability in morphological characters and ecological adapta- tion (see Stubbe and Passarge, 1979; Neuhaus and Schaich, 1985 for reviews) within the subspecies C. capreolus capreolus the existence of various ecotypes or even "locality races" has been hypothesised (Reimoser, 1986), which might lead to the expectation of comparatively high genetic differentiation at the molecular level. Concerning its ecological strategy of adaptation among deer C. capreolus can be designated as $r$-strategist (Harrington, 1985; Gossow and Fischer, 1986; Gossow, personal communication). Within the $r-K$ continuum $r$-selected roe deer, compared to $K$ selected deer species, show rapid development, high $r_{\max }$ (multiple births), early reproduction, shorter length of life etc; they are "opportunists".

$R$-selection leads to high productivity in unstable (short-lived, unpredictable) habitats such as the weedy cover of new clearings in forests, where roe deer live preferentially. In contrast $K$ strategy with slower development and greater competitive ability leads to increasing efficiency of utilisation of environmental resources in stable (longer-lived) habitats like old climax forests. Correlates of $r$ - and $K$-selection in ecology and behaviour were published by Pianka (1970), Wilson (1975) and Barash (1980). According to a hypothesis derived by Harrington (1985) $r$-strategists should be genetically less variable within populations than $K$-strategists. He argues that low genetic variation would prevent inbreeding depression, which might occur during dramatic changes in population sizes (which are more likely 
to occur in $r$-strategists than in $K$-strategists) or when new populations are founded by a small number of colonising individuals. Harrington's hypothesis is supported by an initial study on roe deer carried out by Baccus et al. (1983), who found comparatively low genetic variation at 19 serum protein and enzyme loci in a sample of 25 individuals. To get more insight into the genetic structure of roe deer populations we investigated a total of 161 individuals representing 5 populations at very different geographic sites in Austria. The results indicate, that at the molecular level roe deer are one of the most variable species yet studied among deer showing considerable genetic diversity within and between local populations. These findings are discussed with respect to the hypotheses mentioned above.

\section{MATERIALS AND METHODS}

Kidney and liver samples from roe deer were collected by local hunters during the hunting season of 1986. In total 161 individuals from five popula- tions inhabiting different regions of Austria were sampled (fig. 1).

Tissues were frozen soon after death of the specimens and stored at $-20^{\circ} \mathrm{C}$ until electrophoresis. Preparation of tissue extracts, electrophoretic and staining procedures were performed according to routine methods (Hartl and Höger, 1986). Peptidases were stained using Lleucyl-L-alanine as substrate. Since no family studies could be carried out, the genetic interpretation of electrophoretic patterns was based on the principles outlined by Harris and Hopkinson (1976) and Harris (1980). The results were also compared with genetic variation in deer described by other authors (see introduction for references).

The following 27 enzyme systems were screened (abbreviation, E.C. number and tissues used are given in parentheses; $\mathrm{L}=$ liver, $\mathrm{K}=$ kidney): sorbitol dehydrogenase (SDH, E.C. 1.1.1.14, L), lactate dehydrogenase (LDH, E.C. 1.1.1.27, K), malate dehydrogenase (MDH, E.C. 1.1.1.37, K), malic enzyme (ME, E.C. 1.1.1.40, K), isocitrate dehydrogenase (IDH, E.C. 1.1.1.42, K), 6-phosphogluconate dehydrogenase (6-PGD, E.C.

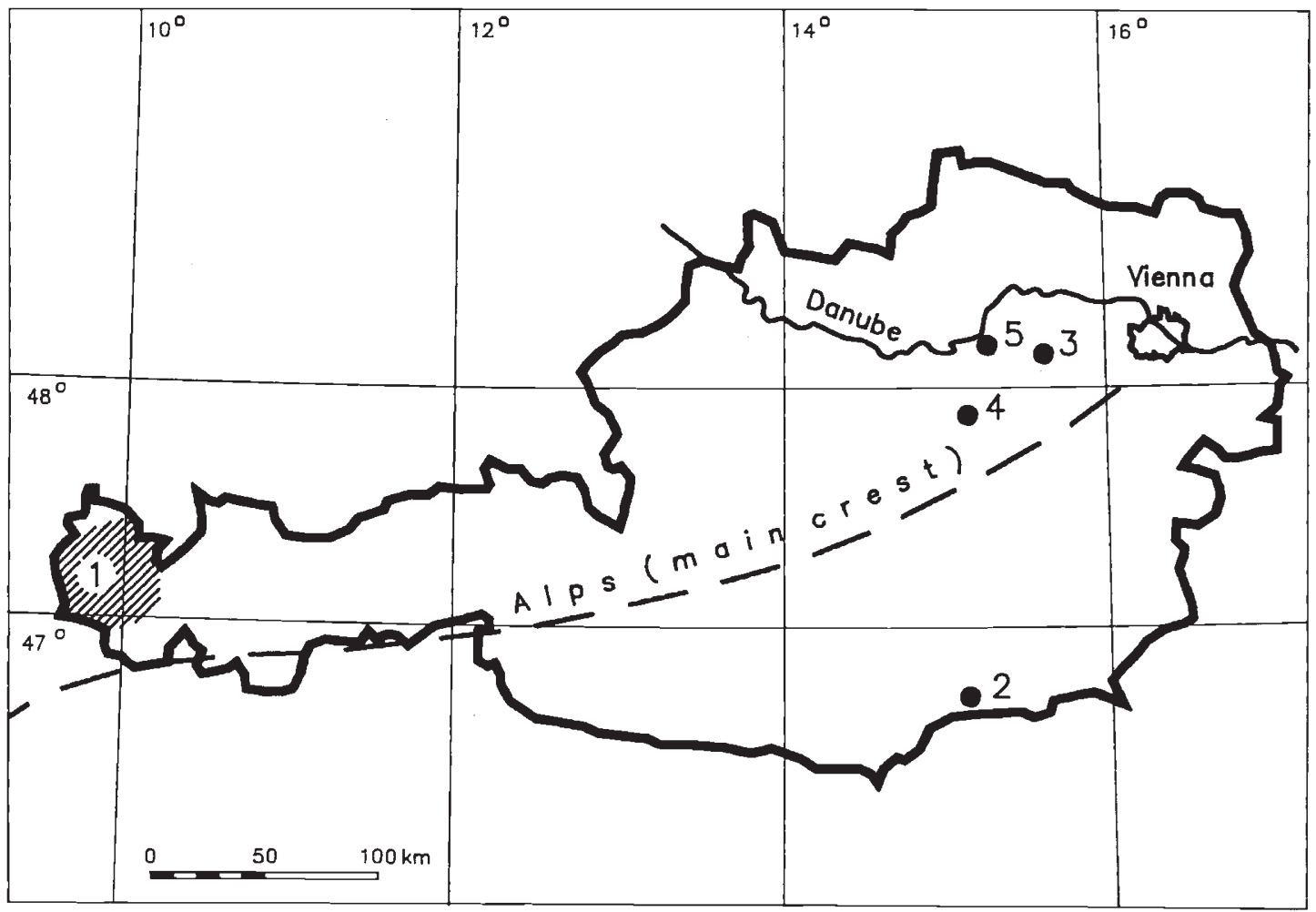

Figure 1 Sampling sites of roe deer in Austria. $1=$ Vorarlberg, $2=$ Soboth (Styria), $3=$ Pyhra (Lower Austria), $4=$ St. Anton $/ \mathrm{J}$ (Lower Austria), 5= Melk (Lower Austria). 
1.1.1.44, K), glucose dehydrogenase (GDH, E.C. 1.1.1.47, L), glucose-6-phosphate dehydrogenase (G-6-PD, E.C. 1.1.1.49, K), xanthine dehydrogenase (XDH, E.C. 1.2.3.2, L), glutamate dehydrogenase (GLUD, E.C. 1.4.1.3, L), NADHdiaphorase (DIA, E.C. 1.6.2.2, K), catalase (CAT, E.C. 1.11.1.6, L), superoxide dismutase (SOD, E.C. 1.15.1.1, K), aspartate aminotransferase (AAT, E.C. 2.6.1.1, K), hexokinase (HK, E.C. 2.7.1.1, L), creatine kinase (CK, E.C. 2.7.3.2, L), adenylate kinase (AK, E.C. 2.7.4.3, L), phosphoglucomutase (PGM, E.C. 2.7.5.1, K), esterases (ES, E.C. 3.1.1.1), alkaline phosphatase (ALP, E.C. 3.1.3.1, K), acid phosphatase (ACP, E.C. 3.1.3.2, K), peptidases (PEP, E.C. 3.4.11, K), aminoacylase-1 (ACY-1, E.C. 3.5.1.14, K), adenosine deaminase (ADA, E.C. 3.5.4.4, L), fumarate hydratase (FH, E.C. 4.2.1.2, L), mannosephosphate isomerase (MPI, E.C. 5.3.1.8, K) and glucosephosphate isomerase (GPI, E.C. 5.3.1.9, K).

At each isoenzyme locus the most common allele in the roe deer of population 1 (Vorarlberg) was designated arbitrarily " 100 ", variant alleles in the same or in other populations according to their relative mobility.

\section{RESULTS}

Screening of 27 isoenzyme systems representing a total of 41 presumptive structural loci revealed polymorphism in 9 isoenzymes: LDH-2, ME-2, DIA-2, AK-1, PGM-1, PGM-2, ACP-1, PEP-2 and MPI. In all cases heterozygote band patterns were consistent with the known quaternary structure of the enzymes concerned.

The following loci were monomorphic for the same allele among the roe deer populations studied: $S d h, L d h-1, M d h-1,-2, M e-1, I d h-1,-2$, 6-Pgd, Gdh, G-6-pd, Xdh, Glud, Dia-1, Cat, Sod-1, -2, Aat-1, -2, Hk-1, -2, Ck, Ak-2, Pgm-3, Es-d, Alp, Acp-2, Pep-1, Acy-1, Ada, Fh, Gpi-1, and -2.

When tested for the Hardy-Weinberg equilibrium, at the polymorphic loci no significant deviation of the observed phenotype distributions from the expected binomial proportions could be detected in any of the populations studied (chisquare test). The allele frequencies, single-locus heterozygosities, average heterozygosities and the proportion of loci polymorphic in each of the populations studied are given in table 1 . Averaged over all populations the proportion of polymorphic

Table 1 Allele frequencies and indices of genetic variation at nine polymorphic loci in roe deer. $1=$ Vorarlberg, $2=\mathrm{Soboth}$, $3=$ Pyrha, $4=$ St. Anton, $5=$ Melk, $p=$ allele frequency, $H\left(H_{0}\right)=$ expected (observed) heterozygosity, $\bar{H}\left(\bar{H}_{0}\right)==\operatorname{expected}$ (observed) average hererozygosity calculated over 41 presumptive genetic loci, $\bar{P}=$ proportion of polymorphic loci, $n=$ sample size

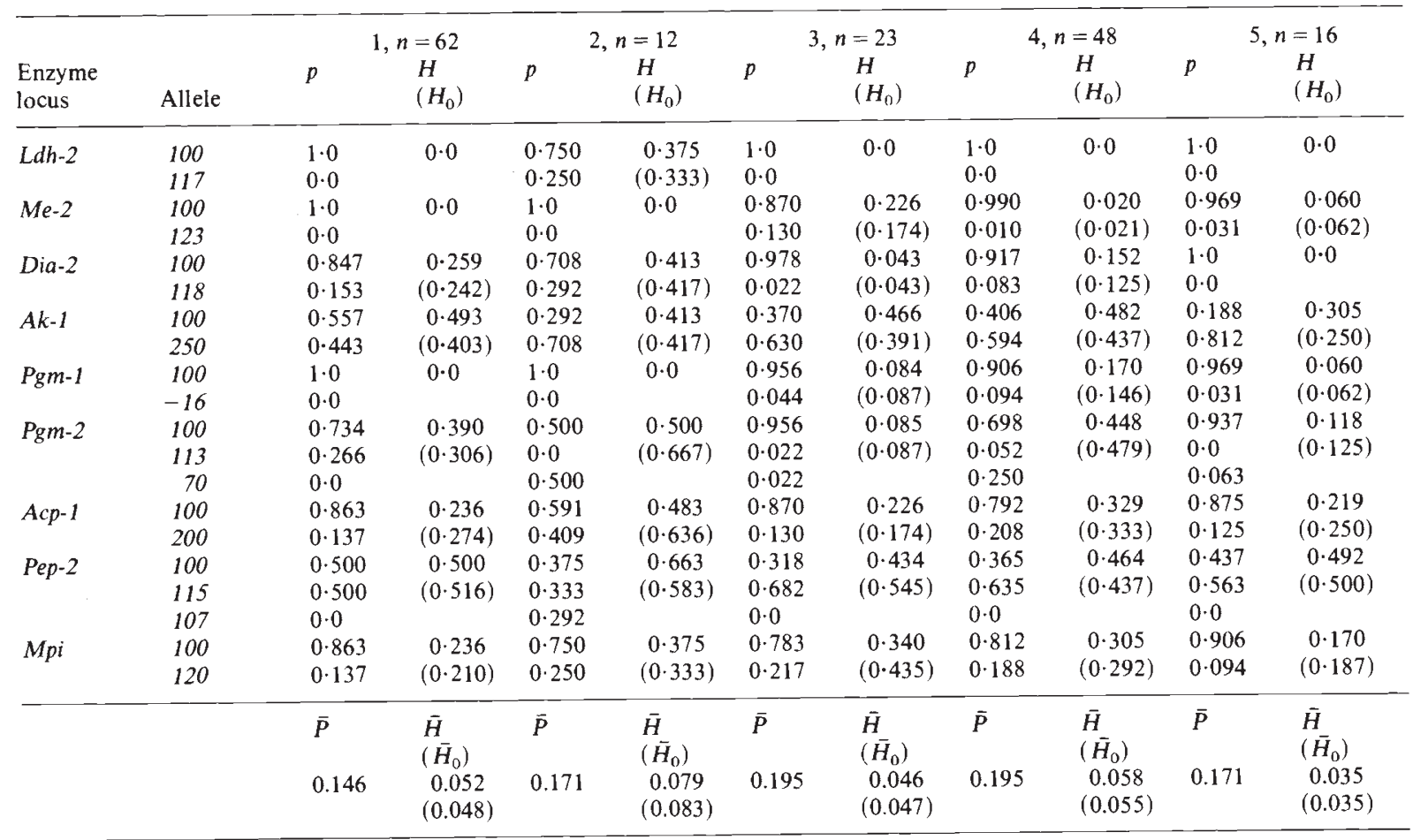


loci $(\bar{P})$ is $17 \cdot 6 \pm 2 \cdot 04$ per cent and expected average heterozygosity $(H)$ is $5.4 \pm 1.63$ per cent.

Genetic relationships between populations were estimated using Nei's (1972) measures of overall genetic identity $(I)$ and standard genetic distance $(D)$. Calculated over all populations mean genetic identity was $0.9931 \pm 0.0049$ and mean genetic distance was $0 \cdot 0069 \pm 0 \cdot 0050$, respectively (detailed values are given in table 2). The total amount of genetic variation was further analysed using Nei's (1975) measures of gene diversity. The average diversity among populations $\left(D_{\mathrm{ST}}\right)$ was 0.0050 and accounted for approximately 8.5 per cent $\left(G_{\mathrm{ST}}=0.085\right)$ of the total gene diversity $\left(H_{\mathrm{T}}=0 \cdot 059\right)$. To show the genetic relationships between the roe deer populations studied a dendrogram was constructed using the UPGMA as described by Nei (1975) based on estimates of standard genetic distance (fig. 2).

Table 2 Matrix of Nei's (1972) measures of genetic identity (I) (above the diagonal) and standard genetic distance (D) (below the diagonal) between the roe deer populations studied

\begin{tabular}{llllll}
\hline & 1 & 2 & 3 & 4 & 5 \\
1 & - & 0.9873 & 0.9958 & 0.9970 & 0.9943 \\
2 & 0.0128 & - & 0.9855 & 0.9919 & 0.9866 \\
3 & 0.0042 & 0.0146 & - & 0.9977 & 0.9981 \\
4 & 0.0030 & 0.0082 & 0.0023 & - & 0.9968 \\
5 & 0.0057 & 0.0135 & 0.0019 & 0.0032 & - \\
\hline
\end{tabular}

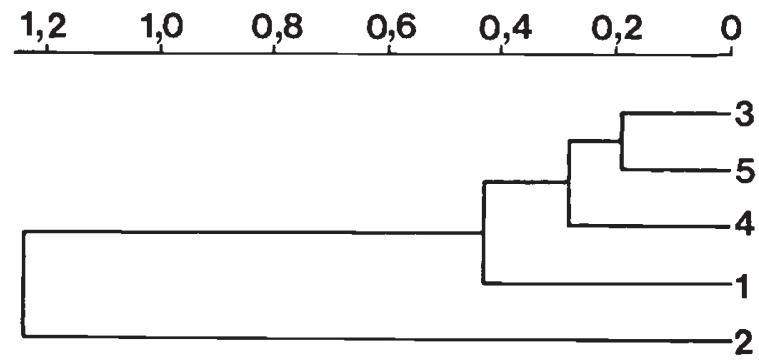

Figure 2 Genetic relationships between the roe deer populations studied. The dendrogram was constructed using the UPGMA as described by Nei (1975) based on Nei's (1972) standard genetic distance $(\times 100)$.

\section{DISCUSSION}

The mean proportion of polymorphic loci and the mean proportion of heterozygous loci per individual detected in the present study are considerably higher than the corresponding values for roe deer obtained by Baccus et al. (1983). Since in spite of different sample sizes the extent of polymorphism between our populations was rather similar, we think that the lower extent of genetic variation detected by Baccus et al. (1983) can be best explained by the restricted number of loci investigated by these authors. Generally the number as well as the composition of enzyme systems and serum proteins studied seem to have an important influence on estimates of genetic variation and genetic divergence (see e.g. Johnson, 1974; Ward, 1977; Sarich, 1977; Gorman and Renzi, 1979; Lewontin, 1985; Hartl and Csaikl, 1987, for further discussion of this problem).

While our results support Nevo's (1984) conclusion that generalist species are genetically more variable than specialist species they provide further evidence against the argument that comparatively large mammals should be genetically less variable than small mammals. This argument was mainly derived from the "environmental grain hypothesis" proposed by Selander and Kaufman (1973) and supported by first electrophoretic studies on large mammals (see e.g. Cameron and Vyse, 1978; Simonsen, 1982). However, when more species and enzyme systems were examined, a considerable amount of biochemical variation was detected also among several species of large mammals (see e.g. Newman et al., 1985; Miller and Hartl, 1986; Hartl and Csaikl, 1987; and the data given in table 3). Thus, in the light of new data emerging, the proposed negative correlation between body size and genetic variation in mammals is invalid or at least very problematic (see Nevo, 1984; Wooten and Smith, 1985, for statistical examination of this problem and for further discussion).

A similar situation can be found with respect to Harrington's (1985) hypothesis emphasising genetic-ecological differences between the two subfamilies of the Cervidae, the Telemetacarpi and the Plesiometacarpi, which are differentiated morphologically by the degree of regression of the lateral metacarpals. Harrington (1985) argues that the Telemetacarpi are $r$-strategists and the Plesiometacarpi $K$-strategists. He writes: ". . . it could be postulated, that genetic variation in the $r$-selected Telemetacarpi is displayed mainly between populations (subspecies), while that in the $K$-selected Plesiometacarpi is displayed within populations-or is at least less segregated". According to our results the indices of genetic variation within populations of roe deer $(\vec{P}$ and $\bar{H}$ in combination, table 1) are among the highest values yet obtained in Cervidae. Since this is the 
Table 3 Genetic variation in deer species. $n I=$ sample of individuals, $n P=$ sample of populations, $n L=$ sample of loci, $\bar{P}_{t}=$ total proportion of polymorphic loci (calculated from the data given in the references), $\bar{P}$ =proportion of polymorphic loci (if more populations are studied the mean $\bar{P}$ is given), $\bar{H}=$ expected average heterozygosity (if more populations are studied the mean $\bar{H}$ is given $),{ }^{*}=$ value calculated by Cameron and Vyse (1978).

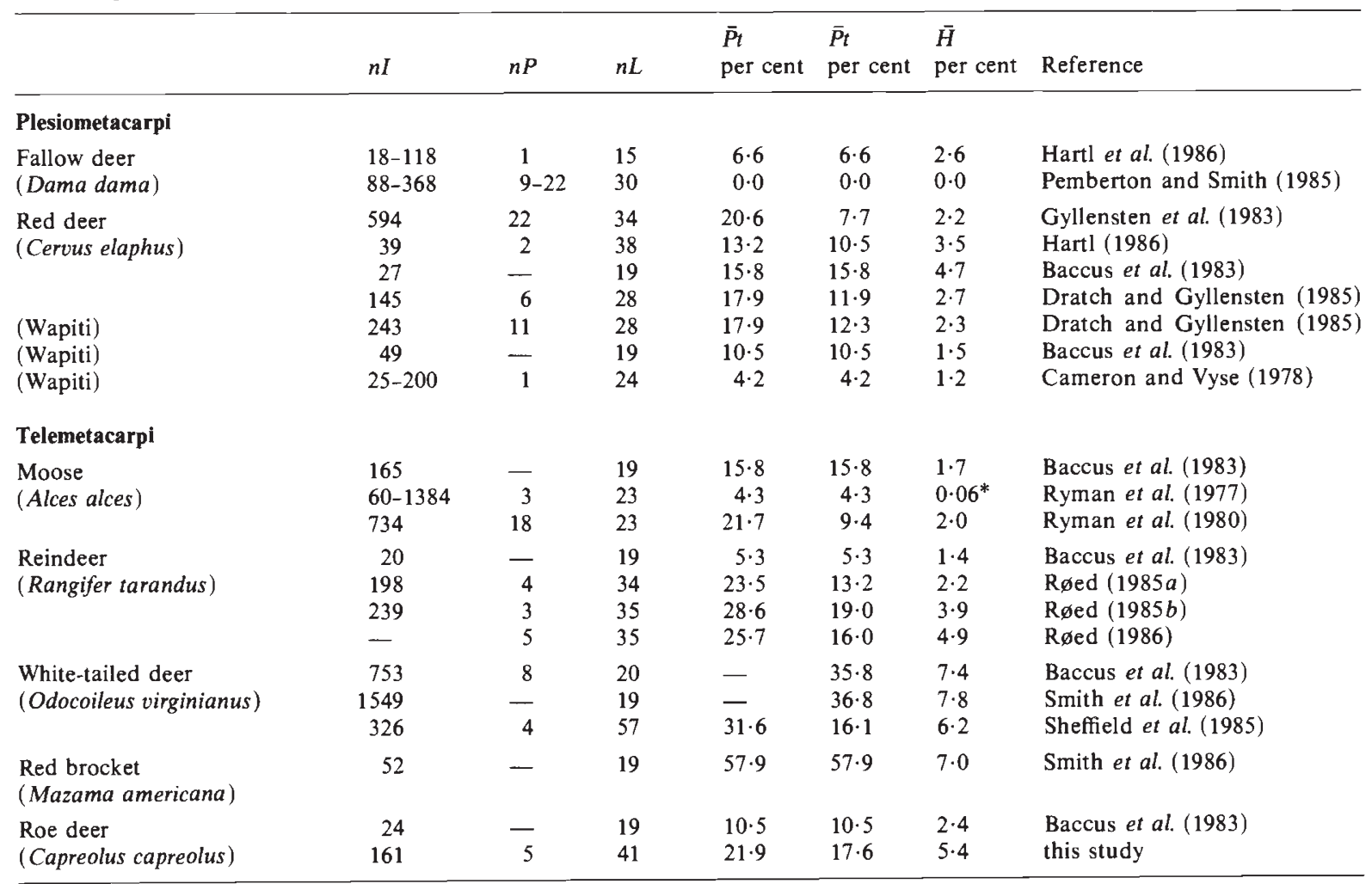

case also in other species of the Telemetacarpi such as white-tailed deer and red-brocket (table $2)$, the postulation that $r$-selected Telemetacarpi exhibit lower genetic variation within populations than $K$-selected Plesiometacarpi is not supported by biochemical genetic data. However, as far as genetic diversity between populations is concerned, the relative amount of differentiation $\left(G_{\mathrm{ST}}\right)$ is somewhat higher in roe deer $\left(G_{\mathrm{ST}}=8.5\right.$ per cent $)$ and in moose $\left(G_{\mathrm{ST}}=9.4\right.$ per cent; Ryman et al., $1980)$ than in red deer $\left(G_{\mathrm{ST}}=5\right.$ per cent; Gyllensten et al., 1983). Thus, this aspect of Harrington's hypothesis may be supported by electrophoretic results, but more comprehensive data, especially on more species of the Plesiometacarpi are needed.

Concerning the remarkable extent of polymorphism among $r$-strategists (table 3 ), besides the possibility of inbreeding depression due to homozygosity of deleterious genes being more likely in genetically variable populations, also the positive correlation between enzyme heterozygosity and fertility (detected, for example, in whitetailed deer by Johns et al. 1977) must be considered. Since high fertility is essential for $r$-strat- egists, many polymorphisms may be preserved by selection in those species and rare alleles may therefore occur in relatively high frequencies (see table 1). If a population bottleneck is followed by rapid population growth (as it is the case in $r$ strategists) not too many of the high frequency polymorphisms will be lost (Nei et al., 1975), but there will still arise considerable allele frequency differences between populations resulting in comparatively high $G_{\mathrm{ST}^{-}}$values. On the other hand no fertility problems were described in fallow deer, a species exhibiting very low levels of biochemical variation (Pemberton and Smith, 1985; Hartl et al., 1986). Besides the explanation that most deleterious genes may have been lost together with the biochemical genetic variation there could be also a lower association between enzyme heterozygosity and fertility among $K$-strategist species. However, in our opinion only a multifactorial approach considering in detail the special ecological, physiological and behavioural features of each species as well as its historical aspects can lead to more comprehensive models on biochemical differentiation. 
The genetic variation between the five Austrian roe deer populations as displayed in fig. 2 provide some interesting indications on the existence of geographically different refugial areas of roe deer during glaciation and on pathways of postglacial immigration of this species into the alpine region. The comparatively large genetic distance of population 2 (Soboth) to all other populations suggests that postglacial immigrations took place from different refugial areas on the two sides of the main crest of the Alps (see fig. 1). Furthermore, it is likely that the main crest of the Alps, with its elevations up to about $4000 \mathrm{~m}$, is an important barrier to gene flow between southern and northern populations at present.

Acknowledgements The authors are indebted to Dipl.Ing. F. Völk (Pyhra), to W. G. Menke (Melk), to Dipl.Ing. G. Kamsker (Prince of Croy's estate management, Soboth) and the local hunters in Vorarlberg and St. Anton for the gift of material and help in sampling. The excellent technical assistance of $\mathbf{A}$. Haiden is gratefully acknowledged.

BACCUS, R., RYMAN, N., SMITH, M. H., REUTERWALL, C. AND CAMERON, D. 1983. Genetic variability and differentiation of large grazing mammals. Journal of Mammalogy, 64, $109-120$

BARASH, D. P. 1980. Soziobiolgie und Verhalten. Paul Parey, Hamburg, Berlin.

CAMERON, D. G. AND VYSE, E. R. 1978. Heterozygosity in Yellowstone Park elk, Cervus canadensis. Biochemical Genetics, 16, 651-657.

DRATCH, P. AND GYLLENSTEN, U. 1985. Genetic differentiation of red deer and North American elk (wapiti). Biology of Deer Production, The Royal Society of New Zealand Bulletin 22, 37-40.

GORMAN, G. C., RENZI, J. JR. 1979. Genetic distance and heterozygosity estimates in electrophoretic studies: effects of sample size. Copeia, 2, 242-249.

GOSSOW, H. AND FISCHER, A. 1986. Alpine RotwildVorkommen im Konflikt mit verschiedenen LandnutzungsInteressen. Tagungsbericht, CIC-Rotwildtagung Graz, 307329.

GYLLENSTEN, U., RYMAN, N., REUTERWALL, C. AND DRATCH, P. 1983. Genetic differentiation in four European subspecies of red deer (Cervus elaphus L.). Heredity, 51, $561-580$

HARRIS, H. AND HOPKINSON, D. A. 1976. Handbook of Enzyme Electrophoresis in Human Genetics. Elsevier/NorthHolland, Amsterdam.

HARRIS, H. 1980. The Principles of Human Biochemical Genetics. Elsevier/North-Holland, Amsterdam.

HARRINGTON, R. 1985. Evolution and distribution of the Cervidae. Biology of Deer Production, The Royal Society of New Zealand, Bulletin, 22, 3-11.

HARTL, G. B. 1986. Genetische Variabilität beim RotwildAuswirkungen anthropogener Einflüsse auf den Genpool von Wildtierpopulationen. Tagungsbericht, CIC-Rotwildtagung Graz, 423-431.
HARTL, G. B. AND HÖGER, H. 1986. Biochemical variation in purebred and crossbred strains of domestic rabbits. Genetical Research Cambridge, 48, 27-34.

HARTL, G. B., SCHLEGER, A. AND SLOWAK, M. 1986. Genetic variability in fallow deer (Dama dama L.). Animal Genetics, 17, 335-341.

HARTL, G. B. AND CSAIKL, F. 1987. Genetic variability and differentiation in wild boars (Sus scrofa ferus L.): comparison of isolated populations. Journal of Mammalogy, $68,119-125$

JOHNS, P. E., BACCUS, R., MANLOVE, M. N., PINDER, J. E. AND SMITH, M. H. 1977. Reproductive patterns, productivity and genetic variability in adjacent white-tailed deer populations. Proc. Ann. Conf. S.E. Assoc. Fish and Wildl. Agencies, 31, 167-172.

JOHNSON, G. B. 1974. Enzyme polymorphism and metabolism. Science 184, 28-37.

LEHMANN, E. VON, SÄGESSER, H. 1986. Capreolus capreolus Linnaeus, 1758-Reh. Niethammer, J. and Krapp, F. (eds) In Handbuch der Säugetiere Europas, Aula-Verlag, Wiesbaden, pp. 233-268.

Lewontin, R. C. 1985. Population genetics. Ann. Rev. Gent., $19,81-102$.

MANLOVE, M. N., SMITH, M. H., HILLESTAD, H. O., FULLER, S. E., JOHNS, P. E. AND STRANEY, D. O. 1976. Genetic subdivision in a herd of white-tailed deer as demonstrated by spatial shifts in gene frequencies. Proc. Ann. Conf. S.E. Assoc. Game Fish Comm., 30, 487-492.

MILLER, C., HARTL, G. B. 1986. Genetic variation in two alpine populations of chamois (Rupicapra rupicapra L.). Zeitschrift für Säugetierkunde, 51, 114-121.

NEI, M. 1972. Genetic distance between populations. American Naturalist, 106, 283-292.

NEI, M. 1975. Molecular Population Genetics and Evolution. Elsevier/North-Holland, Amsterdam.

NEI, M., MARUYAMA, T. AND CHAKRABORTY, R. 1975. The bottleneck effect and genetic variability in populations. Evolution, 29, 1-10.

Neuhaus, A. H. AND SCHAICH, K. 1985. Das Rehwild (founded by F. von Raesfeld), Paul Parey, Hamburg, Berlin.

NEVO, E. 1983a. Adaptive significance of protein variation. Oxford, G. S. and Rollinson, D. (eds). In Protein Polymorphism: Adaptive and Taxonomic Significance, Academic Press, London, New York, pp. 239-282.

NEVO, E. 1983b. Population genetics and ecology: the interface. Bendall, D. S. (ed.). In Evolution from Molecules to Men, University Press, Cambridge, pp. 287-321.

NEVO, E., Bliles, A. AND BEN-SHLOMO, R. 1984. The evolutionary significance of genetic diversity: ecological, demographic and life history correlates. Mani, G. S. (ed.). In Evolutionary Dynamics of Genetic Diversity. Lecture Notes in Biomathematics, Springer-Verlag, Berlin, pp. 13213.

NEWMAN, A., BUSH, M., WILDT, D. E., VAN DAM, D., FRANKENHUIS, M.Th., SIMMONS, L., PHILLIPS, L. AND O'BRIEN, S. J. 1985. Biochemical genetic variation in eight endangered or threatened felid species. Journal of Mammalogy, 66 256-267.

PEMBERTON, J. M. AND SMITH, R. H. 1985. Lack of biochemical polymorphism in British fallow deer. Heredity, 55, 199-207.

PIANKA, E. R. 1970. On $r$ - and $K$-selection. Clutton-Brock, T. H. and Harvey, P. H. (eds). In Readings in Sociobiology, W. H. Freeman \& Co, Reading, San Francisco.

RAMSEY, P. R., AVISE, J. C., SMITH, M. H. AND URBSTON, D. F. 1979. Biochemical variation and genetic heterogeneity in South Carolina deer populations. Journal of Wildlife Management, 43, 136-142. 
REIMOSER, F. 1986. Basisinformation Rehwild und Umwelt. Allgemeine Forstzeitschrift, 49, 1216-1217.

RøED, K. H. 1985a. Genetic variability in Norwegian semidomestic reindeer (Rangifer tarandus L.). Hereditas, 102, $177-184$.

RøED, K. H. $1985 b$. Comparison of the genetic variation in Svalbard and Norwegian reindeer. Canadian Journal of Zoology, 63, 2038-2042.

RøED, K. H. 1986. Genetic variability in Norwegian wild reindeer (Rangifer tarandus L.). Hereditas, 104, 293-298.

RYMAN, N., BECKMAN, G., BRUUN-PETERSEN, G. AND REUTERWALL, C. 1977. Variability of red cell enzymes and genetic implications of management policies in Scandinavian moose (Alces alces). Hereditas, 85, 157-162.

RYMAN, N., REUTERWALL, C., NYGREN, K. AND NYGREN, T. 1980. Genetic variation and differentiation in Scandinavian moose (Alces alces): are large mammals monomorphic? Evolution, 34, 1037-1050.

SARICH, V. M. 1977. Rates, sample sizes, and the neutrality hypothesis in evolutionary studies. Nature, 265, 24-28.

SELANDER, R. K., KAUFMAN, D. W. 1973. Genic variability and strategies of adaptation in animals. Proc. Natl. Acad. Sci. USA, 70, 1875-1877.

SHEFFIELD, S. R., MORGAN, R. P. II, FELDHAMER, G. A. AND HARMAN, D. M. 1985. Genetic variation in white-tailed deer (Odocoileus virginianus) populations in Western Maryland. Journal of Mammalogy, 66, 243-255.
SIMONSEN, V. 1982. Electrophoretic variation in large mammals II. The red fox, Vulpes vulpes, the stoat, Mustela erminea, the weasel, Mustela nivalis, the pole cat, Mustela putorius, the pine marten, Martes martes, the beech marten, Martes foina, and the badger, Meles meles. Hereditas, 96, 299-305.

SMITH, M. H., BACCUS, R., HILLESTAD, H. O. AND MANLOVE, M. N. 1984. Population genetics of the white-tailed deer. Halls, L. (ed.). In Ecology and Management of White-tailed deer, Stackpole Books, New York, 119-128.

SMITH, M. H., BRANAN, W. V., MARCHINGTON, R. L., JOHNS, P. E. AND WOOTEN, M. C. 1986. Genetic and morphologic comparisons of red brocket, brown brocket and whitetailed deer. Journal of Mammalogy, 67, 103-111.

STubBe, C. AND PASSARGE, H. 1979. Rehwild, VEB Deutscher Landwirtschaftsverlag, Berlin.

WARD, R. D. 1977. Relationship between enzyme heterozygosity and quaternary structure. Biochemical Genetics, 15, 123135.

WILSON, E. O. 1975. Sociobiology-The New Synthesis. Havard University Press, Cambridge, MA, London.

WOOTEN, M. C. AND SMITH, M. H. 1985. Large mammals are genetically less variable? Evolution, 39, 210-212. 